\title{
The Interactive Effect of Resource Seeking Foreign Direct Investments (RS-FDI) and Economic Growth in Nigeria: Evidence from Niger Delta
}

\author{
Dr Endurance Oriakhi \\ Abertay University Dundee. United Kingdom
}

\begin{abstract}
The oil and gas sector, which is governed by the source of income, receives the majority of foreign direct investment (FDI) inflows in Nigeria. This study established that natural resources are the driving force behind MNEs' internalisation efforts in the country. As a result, the impact of resource-seeking foreign direct investments (RSFDIs) in the Niger Delta on Nigeria's economic growth was critically analysed in this study. To achieve the research goal, the study looked into how RSFDIs affect economic growth. The data for the study include RSFDI and GPD growth which was obtained from important stakeholders in the oil and gas industry in the Niger Delta. The Central Bank of Nigeria, the National Bureau of Statistics, and the World Bank provided additional important statistics. The research variables were estimated using Ordinary Least Square (multiple) regression approaches. The findings reveal that RSFDI, and GDP have a positive correlation. The connection, though, is negligible. The conclusion drawn in the research is that RSFDI has not been an effective contributor to economic growth in the Niger Delta due to profit repatriations.
\end{abstract}

Keywords: Resource Seeking FDI, Economic growth, Niger Delta, Employment and trade Theory

DOI: $10.7176 / \mathrm{JESD} / 12-18-04$

Publication date:September $30^{\text {th }} 2021$

\subsection{INTRODUCTION}

Economic growth has occasionally resulted in previously unheard-of levels of economic disparity, particularly among developing countries (Muinelo-Gallo and Roca-Sagales, 2011). Another major issue in developing economies, according to Khachoo and Khan (2012), is a lack of sufficient internal savings to sustain economic development and investment needs. However, it is also stated that economic expansion leads to increased national wealth, which is beneficial to the economy (Pogge, 2008). In developing countries, the issues are generally unequal wealth distribution among the population rather than wealth growth at the state level. Nigeria's population and economy place it at the crossroads of the African continent. In 2018, the country had a GDP of \$397.27 billion and a population of over 195 million people (World Bank, 2019). Nigeria is qualified to play a pivotal role in Africa. These figures are significant enough to entice foreign direct investment into the country. Nigeria accounts for over $70 \%$ of total FDI inflows to West Africa, which is dominated mostly by the oil sector (World Bank, 2014). Political instability, a bad macroeconomic policy landscape, insecurity, limited infrastructure, and bureaucratic processes have all contributed to a decrease in FDI inflows recently (UNCTAD, 2015).

Nigeria is primarily seen as a secular country with a diverse and developed religious landscape. Muslims make up 51.6 per cent of the population, while Christians make up 46.9\%, according to a 2013 estimate by the Central Intelligence Agency (CIA), World Factbook (2019). Traditional worshippers and those in the unspecified category make up 0.9 per cent and 0.5 per cent of the total population, respectively. In Nigeria, the expansion of religion has a spatial distribution across the country's geographical areas. The southern part of the country is largely dominated by Christianity, while Islam dominates the northern and western parts of the country. The practice of the traditional beliefs, often termed indigenous beliefs, is mostly curtailed within specific local communities

The Federal Government's political framework has resulted in growing expenditures for operational and wage payment objectives. As a result of the increased recurrent spending, monies allocated to capital projects are frequently insufficient (Iyoha et al., 2015). The budget study shows a continually larger recurring expenditure relative to expenditures on infrastructural development across the country since the re-emergence of democracy in 1999. According to an OECD analysis from 2015 on the rationalisation and restructuring of the Federal Government's parastatals, Nigeria's 263 statutory entities employ an estimated 30,000 people. This essentially makes the cost of governance in Nigeria among the highest globally (Okeke and Eme, 2015).

According to Ejuvbekpokpo (2012), a unit increase in recurrent administrative expense is linked to a 0.52 unit decrease in GDP (GDP). The African Development Bank's (ADB) Africa Infrastructure Country Diagnostic Report attributes significant economic growth (50 per cent) to increased infrastructure investment. Nigeria's present ranking of 26th on the Africa Infrastructure Development Index is due in part to its poor capital spending (ADB, 2017a). Oil generated $87.7 \%$ of foreign exchange profits, while the service sector contributed $50 \%$ of 
GDP (Allwell, 2018). The contributions of the service sector to Nigeria GDP has experienced over $80 \%$ growth between 2006 and 2016. This astronomical growth in the service sector has been linked to several factors, which includes supportive government policies, increased foreign direct investment (FDI), relatively stable macroeconomic and political climate. The Nigeria service sector accounts for almost $50 \%$ of all new projects funded by private inward FDI since 2009 (Oh, 2017).

Over $90 \%$ of Nigeria's foreign exchange profits came from the oil sector (Shell, 2019). As a result, the country's foreign exchange reserve is highly correlated with global oil prices. Prior to the global financial crisis, a time of large foreign reserves coincided with a period of high oil prices, as seen in 2007-2008. Between 2011 and 2014, before the global drop in oil prices, there was another increasing trend in foreign reserves. In 2017, the rise in global oil prices resulted in a steady increase in oil trade earnings and Nigeria's existing foreign reserves. Capital inflows indicated by the volume of Foreign Direct Investment (FDI), Foreign Portfolio Investment (FPI) and other investments have a significant impact on the macro-economic environment. Investment in the oil sector or (and) oil-related assets still form the bulk of FDI in Nigeria.

In the first quarter of 2017, the federal government released its Economic Recovery and Growth Plan in response to the biggest economic downturn in over 20 years, which occurred in 2016. The four-year plan (20172020) is aimed at reversing the economy's downward trend and boosting growth across all sectors of the Nigerian economy (MBNP, 2017). The plan has three broad strategic goals: recovering growth, investing in people, and improving the economy's global competitiveness. The policy aspires to place Nigeria among the top 100 countries in the world when it comes to ease of doing business. It also incorporates action meant to boost investment in the non-oil sectors of the economy.

Having stated that, it is necessary to fully explain this study on Nigeria's oil and gas sector in order to provide information on the influence of FDI from the oil and gas industry on the Nigerian economy and society. The central focus of this study is the examination of the impact of resource-seeking foreign direct investment (RS-FDI) on the growth and development of the Niger Delta region of Nigeria. Finally, the research will look into the relationship between RS-FDI and Nigeria's GDP growth.

\section{Review of Literature}

\subsection{Theoretical framework}

\subsubsection{Classical Trade Theories}

One of the earliest theories that explain the rationale for FDI is the classical trade theory of absolute advantage, as propounded by Adam Smith in 1776. In its purest form, the theory of absolute advantage states that each country has an absolute advantage with unique capabilities in the production of certain goods and specialised services over other countries in the face of a similar amount of resources (Schumacher, 2012). The theory further asserts that given this absolute advantage, countries should focus on the production of those goods and services in which they have a comparative advantage over other countries. The advent of free trade and drive for specialisation in trade between countries is thus evidence of the practice of the theory of absolute advantage. Dima (2010) argued that trade liberalisation facilitated income generation by countries, which is consistent with the absolute advantage of the theoretical proposition. In contrast, the classical trade theory provides a reliable and essential foundation to understand the reasons for firms' drive for international expansion, which further explains the rationale for FDI. Zhang (2008), however, argued that the classical trade theory failed to provide an economic theory on international trade despite its essential contribution to understanding the dynamics of international business.

The theory of comparative advantage by David Ricardo in 1817 is a further refinement of the theory of absolute advantage. Ricardo argued that more profit accrued to countries when they focus on producing goods in which they have a comparative advantage (Zhang 2008). According to Ricardo's proposition, there is the high mobility of the factors of production within a country and low mobility across geographical boundaries (Costinot and Donaldson, 2012). Ricardo's theory further stated reasons for goods to be highly mobile within and across geographical boundaries. A zero-transportation cost should be incurred by applying this theory (Cukrowski and Fischer, 2000). For example, China has become a destination for producing goods for the international market. It produces at a lower cost than other countries producing the same goods. Due to this, China has a comparative advantage in the area of cost-effectiveness.

Ricardo also suggested the adoption of technology to overcome the impact of the diminishing return on land (Zhang, 2008). Furthermore, the comparative advantage theory considers labour as an input factor within the country with a constant cost per unit of the item produced (Sapsford, 2008). This theory explains that economic development can easily be attained with the help of comparative advantage. The economy grows as a result of the transactions at the individual level. Also, when firms follow the comparative strategy, the economy is impacted positively. Despite its contribution to the understanding of international trade, comparative advantage theory minimises the contribution of various industries (Sapsford, 2008). Over the years, economists and researchers have agreed that growth in international trade improves human welfare, economic growth and 
development. Theorists have provided justifications for free trade from Adam Smith's theory of absolute advantage to David's Ricardo's comparative advantage.

Other economists like Heckscher and Ohlin (1935) expanded on Ricardo's theory of comparative advantage to the theory of factor proportion. The theory of factor proportion assumes that if two countries interact in international trade with each having two different factors of production and two unique products, each country is better placed to derive a comparative advantage over the other by exporting goods in which it has the highest factor proportion relative to other countries (Keuschnigg, 1999). Heckscher and Ohlin developed the general equilibrium model (also called the Heckscher-Ohlin model) to argue that free trade leads to the growth of real national income compared to restrictive trade barriers (Moon and Pino, 2016). Heckscher-Ohlin theory explains how differences in factor endowments are consistent with the theory of comparative advantage. This theory acts as the backbone for international trade. According to the theory, if the two countries produce the same products by using the same labour, then they export the product which is more abundantly produced in one country.

Rybczinski's 1955 theorem also explains how changes in factor endowment influence the output of goods under the condition of sustained employment (Marcus, Hugo and Christis, 2009). The Rybczinski theorem stated that an increase in a country's factor endowment, such as labour, produces an increase in output of goods which uses the factor intensively and leads to a decrease in the output of other goods. The Stolper-Samuelson theorem in 1941, on the other hand, states that while open international trade benefits from the abundant factor, it is detrimental to the scarce factor. It thus provides insights into why governments may impose barriers to trade on some abundant resource to avoid disruption of income distribution within the country. The Stolper-Samuelson theorem provides details of how proceeds from international trade are distributed among the owners of the factors of production.

According to classical trade theories, international trade plays a crucial role in the economic growth and development of countries due to the distribution of acquired wealth to facilitate the development of key sectors and infrastructure as well as the provision of employment and improving the standard of living of its citizens (Morgan and Katsikeas, 1997). According to Buckley and Ghauri (2015), one key driver of international trade and economic development is the need to export goods to other countries to generate income, often with the domestic production of imported raw materials from other countries. Thus, despite differences in natural resources, a country can export a commodity just because of the comparative advantage of locally developed technologies at lower costs (Negichi, 2014). The application of the theory of comparative advantage is growing due to its simplicity, universality and power (Buckley and Ghauri, 2015). One limitation of the classical trade theory, however, is the inability to explain the reasons for the relative difference in resource advantages between countries. Other authors have propounded theories such as neo-classical trade theory to address this limitation.

\subsubsection{Classical (Economic) Growth Theory}

The classical growth theory (also called Malthusian theory) describes a condition of diminishing output in the face of exploding population and limited natural resources (Salvadori and Signorino, 2017). The high rate of population growth is measured using real subsistence income (real GDP per person), which leads to a decrease in capital per hour of labour. Therefore, the classical growth theory argues that a temporary increase in real GDP per person leads to a reduction of the real GDP per person (Buckley and Ghauri, 2015). The classical model proponents such as Adam Smith, Thomas Malthus and David Ricardo agree that in the competition between population and technological growth, a widening gap exists with technology in the lead because there must exist a natural upper limit to population expansion (Harris, 2007).

Adam Smith argues that economic growth is made up of each nation's working population, which is employed in productive labour such as agriculture and manufacturing sectors. In his view, productivity is increased depending on the number of workers, efficiency of the workers and the accumulation of capital (Lanza, 2012). However, at a time in the future, stagnation occurs when economic growth outruns technological advancement. Technology development relies on capital investment such as FDI to increase production from automation and greater division of labour. The classical economic theory also identified the significant role of entrepreneurs and advances in technology, which increases productivity and higher real GDP per person (Buckley and Ghauri, 2015).

Critics of the classical growth theory have argued that it focuses on the 'pessimistic' aspect of economic growth (Harris, 2007). For instance, the classical growth theory assumes an agrarian economy with diminishing fertility of the soil with reducing output and growth (Salvadori and Signorino, 2017). It predicts that FDI creates investment opportunities through international trade and points out the role of technology in the transformation of production output. However, the theory posits that despite technological advancement, the real income (real GDP per person) is always pushed back toward the subsistence level (Buckley and Ghauri, 2015).

\subsection{Foreign Direct Investment (FDI)}

Different authors have defined foreign Direct Investment (FDI). For example, Patterson et al. (2004) describe FDI as a direct investment relationship established when the investor(s) has acquired $10 \%$ or more of the 
ordinary shares and associated voting rights in a foreign-based enterprise. The Organization of Economic Cooperation and Development-OECD-(2008) describes FDI as a lasting and strategic involvement of an investor based in one economy in another economy based abroad. In other words, FDI is defined as the strategic involvement of a home-based investor in a foreign-based enterprise, evidenced by the investment of a minimum of $10 \%$ of the equity. The OECD's definition implies a long-term investment strategy outside the home country of the investor and to have physical structures on the ground such as production facilities, capital goods and inventories.

A distinguishing feature of FDI is that it has absolute management control in a foreign enterprise acquired and significant influence over the assets purchased (Bjorvatn, 2008). The OECD's definition of FDI is adopted for this study. The adoption of this definition stems from the encompassing nature of the definition. To comprehend the broad approach to the OECD definition, a look at the word 'lasting' and the phrase 'strategic involvement' will be helpful. First, the foreign investor has the intention to commit to the host country over the long term and to operate a business. Secondly, the definition assumes that foreign investors are always strategic in their involvement with the home country and are engaged in vital participation in the sense that they do choose a specific sector of the economy to commit their capital (Ali and Malik, 2017).

While FDI has both inward and outward components, it is the inward aspect that most countries seek to attract. Inward FDI is determined by many factors, including the availability of natural resources, viable markets, strategic assets and efficiencies in the host country. Inward FDI is also influenced by the political environment, economic condition, human capital, etc. Measuring FDI is critical so that countries seeking FDI can properly understand the direction of flows and make policies for optimising each type of inflow. Understanding the benefits and shortcomings of FDI will enable host countries to implement policies that will enable them to minimise the negatives and maximise the positives for their countries to reap the full benefits of FDIs (Wacker, 2016; Ajide and Osode, 2017).

In many developing countries of Africa, FDI constitutes a core aspect of economic development strategy (Ayanwale, 2007) due to a strong linkage between an increase in FDI and high economic growth and strong corporate performance in many parts of the world (UNCTAD, 2007; Adams, 2009). Some African countries like Nigeria have, therefore, introduced new measures to attract FDI inflows, such as creating a favourable business environment for foreign investors (UNCTAD, 2007). FDI can impact positively on a host country's economy when there is diversification, absorptive capacity, liberalised markets, educated workforce and infrastructure (Carkovic and Levine, 2002). It is a way of stabilising the economy of developing countries even as these translate to a comfortable and enabling environment for FDIs by the host country.

Across the world, the European region accounts for the most significant sources of FDI, with $85 \%$ of global FDI, amounting to US\$576 billion (UNCTAD, 2016). The dominant countries of origin for FDI in Europe are Germany, the United Kingdom (U.K.) and the Netherlands. North America, with a combined outflow of US\$367 billion, is also a vital source of FDI, followed by the Asia-Pacific region, whose outflow stood at US\$129 billion (UNCTAD, 2016). About $20 \%$ of Nigeria's FDI comes from the U.K., while other significant contributing countries are Brazil, Italy, France, the Netherlands and South Africa (Inekwe, 2014). The dominant countries of origin for FDI in Asia include the People's Republic of China, Hong Kong and Singapore (Hattari and Rajan, 2009), with China's FDI in Nigeria worth about US\$6 billion (Inekwe, 2014).

\subsection{Resource-Seeking FDI (RS-FDI)}

Resource seeking foreign direct investment (RS-FDI) considers the location where the costs of doing business or production costs are cheaper. Thus, factors such as the cost, quality of labour force and the level of development of infrastructure are very important factors that drive RS-FDI (Inekwe, 2014). Availability of natural and human resources is another motive for organisations pursuing FDI in a foreign country. According to Dunning (2000), some examples of resources sought by investors include agricultural produce, unskilled labour and oil and gas resources. The availability of natural resources tends to attract and sustain FDI inflows into a country or region. For example, in Nigeria, oil and gas resources production and exportation account for $67 \%$ of the nation's total revenue inflow; this is evidence of RSFDI reported by Nigeria Extractive Industries Transparency Initiatives (NEITI, 2017). Firms invest in a foreign country to secure access to natural resources, gain locational advantages and access potential huge markets (Gonchar and Philipp, 2013).

Akhtaruzzaman, Berg and Lien (2017) argue that the growing interest of China in emerging economies in Africa is due to the availability of natural resources in the region. MNEs' investment is often driven by the availability of natural resources and a desire to out-perform local competitors through the deployment of cuttingedge technology (Gonchar and Philipp, 2013). However, it has been argued that resource-seeking FDI is not the best route to liberalising the economy to the global market (Kinoshita and Campos, 2003) because low wages for labour attracts many FDIs and flexibility in trade policies by government loosen restrictions of the economy to a global market.

Investors seeking resource advantage such as agricultural raw materials and inputs to drive down the cost of 
production is another example of resource-seeking FDI. In many instances, the host country often lacks the technological capacity to support local production of finished products; thus, the emergence of investors bearing FDI (Gonchar and Philipp, 2013). Inekwe (2013) also cited low human capital development, unfavourable regulatory environment, a high degree of uncertainty and high dependence on primary commodities exports as some of the FDI constraints. Other constraints to FDI flows in Africa are poor governance, corruption and poor image abroad (Anyanwu, 2006). However, despite these constraints to FDI flow, many investors are still attracted by the high rate of return on investments, especially in Nigeria, which accounts for the highest FDI flow in Africa (Inekwe, 2013; Ogunkola and Jerome, 2006).

\subsection{Benefits of FDI}

The capacity of FDI to generate employment can be observed as increased production capacity in the economy (Brincikova and Darmo, 2014). The inflow of capital into host economies as a result of FDI increases the demand for labour, hence the reduction in unemployment levels (Hale and $\mathrm{Xu}, 2016$ ).

The large presence of FDI equally results in to increase in wages because of the increase in the demand for labour (Hale and $\mathrm{Xu}, 2016$ ). FDI has also been reported to contribute to improvement in trade, staff and firmlevel productivity (Banerji, 2014). According to Brincikova and Darmo (2014), FDIs brings about an expansion in aggregate demand and supply, which serves as incentives for local businesses to expand their production and be more profitable in the long run.

The inflow of FDI has also been reported to increase a host country's national income, drive productivity and increase export earnings (Gorg and Greenaway, 2003). However, there should be a delay in the repatriation of accrued profits and export earnings to ensure a sustained impact on the host economy. Other benefits of FDI include the transfer of skills and technological innovation, which contributes to the human capital development of the host country (Gorg and Greenaway, 2003). Aside from capital, most foreign investors come into host countries with new knowledge, skills and technologies that benefit the host countries (Perri and Peruffo, 2016).

\subsection{Shortcomings of FDI}

Despite the benefits of FDI inflows, some studies have identified some shortcomings. For example, Jude (2014) argued that FDI reduces the number of domestic investments due to the "crowding out" effect of FDI. According to Agosin and Machado (2005), this may be due to the non-realisation of the expected benefits of FDI. Also, the concentration of FDI in one sector with the exclusion of another sector could lead to an "industry dependency effect", leaving the country vulnerable to shocks (Gokmenoglu, Bekun and Taspinar, 2016). This effect is observed in Nigeria, where the concentration of investment in the oil and gas sector leads to depletion of investment in manufacturing and service sectors, leaving the country vulnerable to shocks. The impact of the decline in global demand for oil led to a slide of the global economy into recession (Dickson and Ezirim, 2017).

Just as in other forms of investment, one of the drawbacks of FDI is the risk that is inherent in it. In committing to FDI, a firm has no guarantee that its investment will yield a positive result. The political environment in many countries is highly unpredictable; firms could lose their investment if an unstable government decides to implement policies that are disadvantageous to FDIs or their line of business. A negative political environment could also lead to the loss of foreign investment because of business seizures. Making a foreign investment in a country where the value of the destination country's currency is higher than that of the home country leads to a higher cost of investment. The home country of a foreign investment stands disadvantaged because the fund that is leaving the country could have been invested in the home country and have a positive effect on the country both in terms of GDP growth and job creation.

There is no doubt that FDI fosters the economic growth of countries. A host country needs to evaluate its circumstances to determine the most suitable FDI strategy to accord priority to ensure that it reaps the positive benefits of FDI. Appropriate measurement of FDI will help countries to understand the scale of FDI inflows, hence able to gauge the effect of these FDIs in their economies. Understanding what drives FDI inflows will help host countries to implement the right policies that will ensure that the right FDIs are attracted to their countries. At the same time, to avoid the pitfalls of FDI, host countries are expected to evaluate the intentions of foreign investors before they are allowed to come into their country.

\subsection{Economic Growth}

According to Allen (2017), economic growth can be defined as the measure of the value of finished goods and services produced by a country based on the value of Gross Domestic Product (GDP). The GDP is a measure of the level of income generated by an economy at a specific time. However, it has been argued that GDP measuring often ignores two critical elements of economic growth, namely inadequate human development and some institutional structures within the economy (Sengupta, 2011). In determining the real value of GDP, all goods and services produced in the economy should be captured, including the government's spending on infrastructure and other social services (Allen, 2017). Economic growth, as measured by GDP, serves as an 
indication of whether an economy is growing, declining or stagnant. GDP measurement also helps to predict the trajectory of economic growth in the future. According to Haller (2012), economic growth is attained when the annual growth rate of the economy's GDP outpaces the population growth within a country. Suppose the annual economic GDP rate is equal to the population growth, stagnation results. A decline in economic growth is recorded when the annual population growth rate is higher than that of GDP growth.

Moreover, the concept of economic growth is defined as the difference between the annual natural logarithm of real GDP per capita of a current year and the natural logarithm of real GDP of a preceding year (Smaouli and Nechi, 2017; Ruiz-Vargara, 2017). Economic growth is typically measured as GDP per capita after taking into consideration the inflation factor, and this involves the measurement of a country's average income (Van den Bergh, 2009). However, it has been observed that GNP (Gross National Product) is a better alternative because it gives an actual income that accrues to a country over time. GDP calculates the total real value of goods and services produced in a country at a point in time, not recognising that some income does not belong to the country irrespective of the fact that they were produced there. GDP includes the income of foreigners in the country, and it excludes the income of its citizens living abroad.

According to Pogge (2008), when growth concern has to do with poverty and the need to achieve higher economic status for citizens, especially in developing countries, GNP serves as a better specific measure. In measuring economic growth, GNP considers the contribution of a country's citizens and businesses domiciled outside the country and excludes the contribution of foreign individuals and businesses domiciled in the local economy. According to Pogge (2008), even though the inadequacy of GDP as a measure of welfare by a large number of economists and policymakers is known, it is still used time and time again. While GDP and GNP are equally regarded as very important measures of a country's economic status (Brezina, 2011), the focus of developing countries is to ensure that the relative welfare of their citizens is enhanced, GNP appears to be more effective in gauging the relative welfare of each citizen (Costanza et al., 2009).

In other to determine the positivity of economic growth, two identifiers, namely potential and actual growth, are described by Haller (2012). The first is the potential for an economy that experiences positive growth in its production, also known as long-term growth. The second is the actual growth that an economy experiences due to an increase in the supply of inputs. The degree of this increase is determined by the quality of the input factors. Therefore, to measure effective economic growth, an economy's real GDP is required (Haller, 2012). Moreover, economic growth has been advocated as a veritable means to achieve poverty reduction in countries (Haller, 2012). Recent studies indicate that economic growth has a positive effect on poverty reduction, especially in developing countries, and that average income growth has been the driving force behind poverty reduction around the globe (Fosu, 2017).

\section{Methodology}

\subsection{Study Area}

The Niger Delta sits directly on the Gulf of Guinea on the Atlantic Ocean in Nigeria. Extending over more than 2000 square miles, it makes up about $7.5 \%$ of Nigeria's landmass. The Delta of River Niger is located within nine coastal Southern States, including all states in the South-South geopolitical zone, Ondo State from the South-West geopolitical zone and Abia and the Imo States in the South-East geopolitical zone, with Akwa Ibom state being the only non-oil producing state. The Niger Delta Region (NGR) till 2000 previously consisted of Bayelsa, Delta and Rivers States, but subsequently, Bayelsa, Delta and Rivers States were added to the NDR.

Being Nigeria's largest wetland, ranked as the third-largest wetland in the world and having the world's second-largest mangrove forest, NDR has a population of over 40 million people (23\% of Nigeria's total population) (National Population Commission, 2006). The population density of NDR is one of the highest in the world, with about 265 individuals per square kilometre. The NDR also encompasses major ecological zones like freshwater, swamp, mangrove, creeks and estuaries.

\subsection{FDI and Economic Growth}

The relationship between FDI and economic growth has been studied by many researchers. Borensztein, De Gregorio and Lee (1998) found that FDI inflows add value to the local economy by facilitating domestic enterprises through the transfer of technology and human capacity development (Lamsiraroj, 2016).

FDI also contributes to revamping the economy through domestic investment and contributing to the growth of other industries supplying input materials (Uttama, 2012). A country's national economic growth strategy is expected to drive poverty reduction and enhance the standard of living (Silber, 2013). FDI flows also serve as an effective mechanism to tackle the menace of poverty and facilitate the growth of countries (Asiedu, 2013). Thus, many governments have intensified efforts to initiate policies that attract FDI inflows into their economies (Shah, 2014).

According to Shah (2014), the level of FDI and capacity to attract foreign investors are greatly influenced by the economic climate, market size and level of infrastructure. This aligns with the views of Akpan, Isihak and 
Asongu (2014), who introduced openness to trade as an additional factor driving the flow of FDI to develop the economies of the BRICS countries (Brazil, Russia, India, China, South Africa) and MINT countries (Mexico, Indonesia, Nigeria and Turkey). Also, Vijayakumar, Sridharan and Rao (2010) added labour cost, currency value and economic growth as factors affecting FDI inflows to BRICS countries. Therefore, it has been suggested that knowledge of the host economy, good infrastructure base, economic freedom, foreign exchange rate stability, trade openness and potential for a higher return on investment helps attract FDIs (Quazi, 2007; Chakrabarti, 2001; Janicki and Wunnava, 2004). Several studies in the past have established a relationship between FDI and economic growth. A study by Pegkas (2015) found a long-run cointegrating relationship between the level of FDI and economic growth in the Eurozone countries. Similarly, in a study of the effect of foreign direct investment in the economy of the South Asian Association for Regional Cooperation (SAARC), Tahir, Estrada and Afridi (2018) found that an increase in the stock of FDI led to economic growth. Also, a study by Fadhil and Almsafir (2015) on the relationship between FDI and economic growth in Malaysia found that an increase in FDI resulted in effective economic growth in the country.

Hypothesis Testing

$H_{0}:$ The RSFDI in the Niger Delta contribute negatively to Nigeria's GDP growth

$H_{1}$ : The RSFDI in the Niger Delta contribute positively to Nigeria's GDP growth.

The reason countries attract and encourage foreign investors is to ensure the continuous growth of their GDP. As GDP increases, hopefully, the economic conditions of individual citizens in the country will also increase. This hypothesis will be tested to conclude if inflows of foreign capital by way of oil and gas RSFDI have led to GDP growth in Nigeria.

\subsection{Source and Type of Data}

Given the quantitative nature of data requirements to achieve the research objective, quantitative data were required to be used to assess the impact of resource-seeking FDI in the Niger Delta on economic growth in Nigeria. The data were collected from the relevant ministries in the Niger Delta States using structured questionnaires. Specific Niger Delta institutions data was collected from including the Federal Ministry of Niger Delta Affairs, the Niger Delta Development Commission (NDDC), oil and gas companies, and nongovernmental organisations. The model for this paper was drawn from the Market Imperfection Theory because it represents the closest explanation to the study of the impact of resource-seeking FDI in the Niger Delta on economic growth in Nigeria. The market imperfection theory explains multinational corporations who are motivated to seek investment opportunities outside of their original country due to structural imperfection in the destination country (Faeth, 2009).

The mathematical model for this study was drawn from an ordinary least squares regression. The mathematical form of the Error Correction Mechanism (ECM) model to be estimated is shown below:

$\mathrm{GDPt}=\mathrm{b} 1+\mathrm{b} 2 \mathrm{RSFDIt}+\mathrm{b} 3 \mathrm{INFRt}+\mathrm{Ut}$

GDP means Gross Domestic Product - Dependent variable

RSFDI means Resource Seeking Foreign Direct Investment.

INFR is infrastructure measured by Gross fixed capital formation (GFCF)

Ut in the equation signified error term.

Equation 1 can be re-written as:

$\mathrm{Ut}=$

GDPt - b1 - b2RSFDIt - b3INFRt

The equilibrium error term links the short-run behaviour of GDP to its long-run value.

The relationship between the dependent variable and the independent variables can be expressed as an ECM:

DGDPt $=\alpha 0+\alpha 1$ DRSFDIt $+\alpha 2$ DINFRt $+\alpha 3$ Ut $-1+$ et

Where $\mathrm{D}$ denotes the first difference operator, and et is a random error term.

Recall that:

$\mathrm{Ut}=$

GDPt - b1 - b2RSFDIt - b3INFRt

Thus equation 3 forms the basis of estimations.

\subsection{Data Analysis}

\subsubsection{Estimation Techniques}

Parameters can be described as descriptive measures of an entire population because it is not practicable to measure and evaluate the whole population. Parameters are fixed constants that do not vary like variables and can, therefore, serve as input for generating the distribution curve from limited data through random sampling of the population. Through the statistical analysis, estimates of parameters (called sample statistics) from the population are carried out as well as the margin of error linked to the parameters. One of the parameter estimates is point estimates which are typically a single predictable value of a parameter. For example, the sample mean is 
a point estimate for the population mean. Another population parameter is confidence intervals which denote a range of values most likely to contain the population parameter.

In carrying out a parameter estimation, one assumption is that all the variables included in the regression equation are stationary. However, in reality, most time series analysis is not stationary, thus limiting the meaning derivable from this estimation technique. To address this gap, the differences between the two-time series are mechanically taken, but this approach does not consider the data outside the scope selected. Newer models, such as cointegration and error correction methods, can address these challenges. Examples of parameter estimation include regression methods, cointegration based techniques and the Johansen technique. Of importance among the cointegration based approaches is the Johansen technique which applies to multivariate models (Johansen, 1991 ; 1995) and thus has been adopted for this study.

Johansen cointegration technique is a very important tool in parameter estimation, especially for time series data because it retains the intrinsic time-series properties of the data, thus capturing estimates of all cointegration relationships in both non-stationary and stationary variables (Harris, 1995). Johansen techniques have some advantages over other cointegration techniques, such as estimation of dynamic error specification (covering long run and short-run dynamics). A first step in the implementation of the Johansen technique is the determination of the order of integration of all variables (Harris,1995; Seddighi, Lawler and Katos, 2000). The second step involves conducting cointegration tests to identify normal long-run relationships in the variables and subsequently estimate using a short-run vector error correction model and ending with residual diagnostics checks (Harris, 1995).

\subsubsection{Diagnostic Checks}

This phase is very important in studying the impact of RSFDI in the Niger Delta region on economic growth in Nigeria because it confirms the outcome of the parameter achieved by the Error correction (ECM) model. Diagnostic controls investigate stochastic attributes of the model, such as residual auto-correlation, heteroskedasticity and normality, etc. The multivariate extensions of the residual tests mentioned above are only applicable to this study. Data were analysed in the next section using the ordinary least square regression.

Data were tested for normality and adequacy using various tools before they were applied to the ordinary least square regression from which conclusions were drawn.

\section{RESULTS AND DISCUSSION}

\subsection{Descriptive Statistics}

This section consists of the display of the data used for the study and the descriptive statistics obtained from the data like the minimum value, maximum, mean, median, and so on. It also shows the time plot and histogram of each of the variables. Table 4.1 below is the data used for this study. It consists of GDP growth rate and resource seeking FDI. The table contains figures from 1994 to 2016.

Nigeria can be characterised as a developing economy with a constantly fluctuating growth rate. The country's economy grew at a rate of $1.94 \%$ in 2018 (World Bank, 2019a). The country's GDP per capita is still at a very low level, and this stood at \$2028 as in 2018 (World Bank, 2019b). This state of Nigeria's economy is reflected in the figures for the Niger Delta states. The observed trend reveals that the GDP varies in an irregular pattern over the years as it steadily increased from 2002, decreased afterwards and increased again in 2010 to start decreasing until 2016 
Table 4.1: Data Presentation

\begin{tabular}{|c|c|c|}
\hline YEAR & GDP GROWTH RATE & RSFDI \\
\hline & $\%$ & $\$$ Million \\
\hline 1994 & 4.250 & 1,960 \\
\hline 1995 & 5.260 & 1,080 \\
\hline 1996 & 6.020 & 1,590 \\
\hline 1997 & 6.550 & 1,540 \\
\hline 1998 & 5.180 & 1,050 \\
\hline 1999 & 5.890 & 1,000 \\
\hline 2000 & 7.030 & 1,440 \\
\hline 2001 & 8.580 & 1,190 \\
\hline 2002 & 13.66 & 1,870 \\
\hline 2003 & 14.83 & 2,010 \\
\hline 2004 & 15.18 & 1,870 \\
\hline 2005 & 14.72 & 4,980 \\
\hline 2006 & 10.47 & 4,850 \\
\hline 2007 & 9.570 & 6,030 \\
\hline 2008 & 9.050 & 8,200 \\
\hline 2009 & 8.910 & 8,550 \\
\hline 2010 & 10.77 & 6,030 \\
\hline 2011 & 10.73 & 8,840 \\
\hline 2012 & 10.42 & 7,070 \\
\hline 2013 & 9.840 & 5,560 \\
\hline 2014 & 7.800 & 4,660 \\
\hline 2015 & 7.140 & 3,130 \\
\hline 2016 & 6.680 & 4,450 \\
\hline
\end{tabular}

Source: Central Bank of Nigeria, compiled by the author

Table 4.2: Descriptive statistics of the variables

\begin{tabular}{|l|l|l|}
\hline VARIABLES & $\begin{array}{l}\text { GDP } \\
\text { GROWTH RATE }\end{array}$ & RSFDI \\
\hline & $\%$ & $\$$ \\
\hline Mean & 9.066522 & $3.86 \mathrm{E}+09$ \\
\hline Median & 8.91 & $3.13 \mathrm{E}+09$ \\
\hline Maximum & 15.18 & $8.84 \mathrm{E}+09$ \\
\hline Minimum & 4.25 & $1.00 \mathrm{E}+09$ \\
\hline Std. Dev. & 3.218515 & $2.66 \mathrm{E}+09$ \\
\hline Skewness & 0.529349 & 0.525109 \\
\hline Kurtosis & 2.329935 & 1.920371 \\
\hline Jarque-Bera & 1.50442 & 2.174034 \\
\hline Probability & 0.471324 & 0.337221 \\
\hline Sum & 208.53 & $8.87 \mathrm{E}+10$ \\
\hline Sum Sq. Dev. & 227.8945 & $1.56 \mathrm{E}+20$ \\
\hline Observations & 23 & 23 \\
\hline
\end{tabular}

Sources: Nigeria Bureau of Statistics, Ministry of the Niger Delta and WDI Compiled by the author

Table 4.2 above shows the descriptive statistics used for this study. The use of SPSS software helped to scan through the data and return the minimum, the middle value (median), maximum of the values, the number of observations for each variable to know if all the variables are equally replicated. The average value of the GDP growth rate is 9.066522; the RSFDI's average value is $386 \mathrm{E}+09$. GDP has the highest maximum level of 15.18. The maximum value of RSFDI is $8.84 \mathrm{E}+09$.

GDP also has a minimum value of $4.25 \%$, RSFDI is at a minimum value of $1.00 \mathrm{E}+09$. Skewness, which also refers to departure, indicate that GDP departs with 0.529349 , while RSFDI departs with the value of 0.525109 . Kurtosis, which refers to the peak of the subjects under consideration, indicates that RSFDI is at its peak at 1.920371; GDP is at its peak at 2.329935. GDP has an uncertainty level of 0.471324 , while RSFDI has 0.337221 as the level of uncertainty.

The median, standard deviation, sum and sum square deviation for GDP are approximately 8.9, 3.2185, 
208.5, and 227.895, respectively; for RSFDI, we have $3.13 \mathrm{E}+09,2.66 \mathrm{E}+09,8.87 \mathrm{E}+10$ and $1.56 \mathrm{E}+20$ respectively. The essence of these descriptive statistical values is to give the researcher ideas and information regarding the distribution in terms of figures. It shows the minimum value a variable has ever produced and the maximum value it has produced over time. Having information about all these will help the researcher to get a clearer view of the interplay of the variables and ease the job of analysing data.

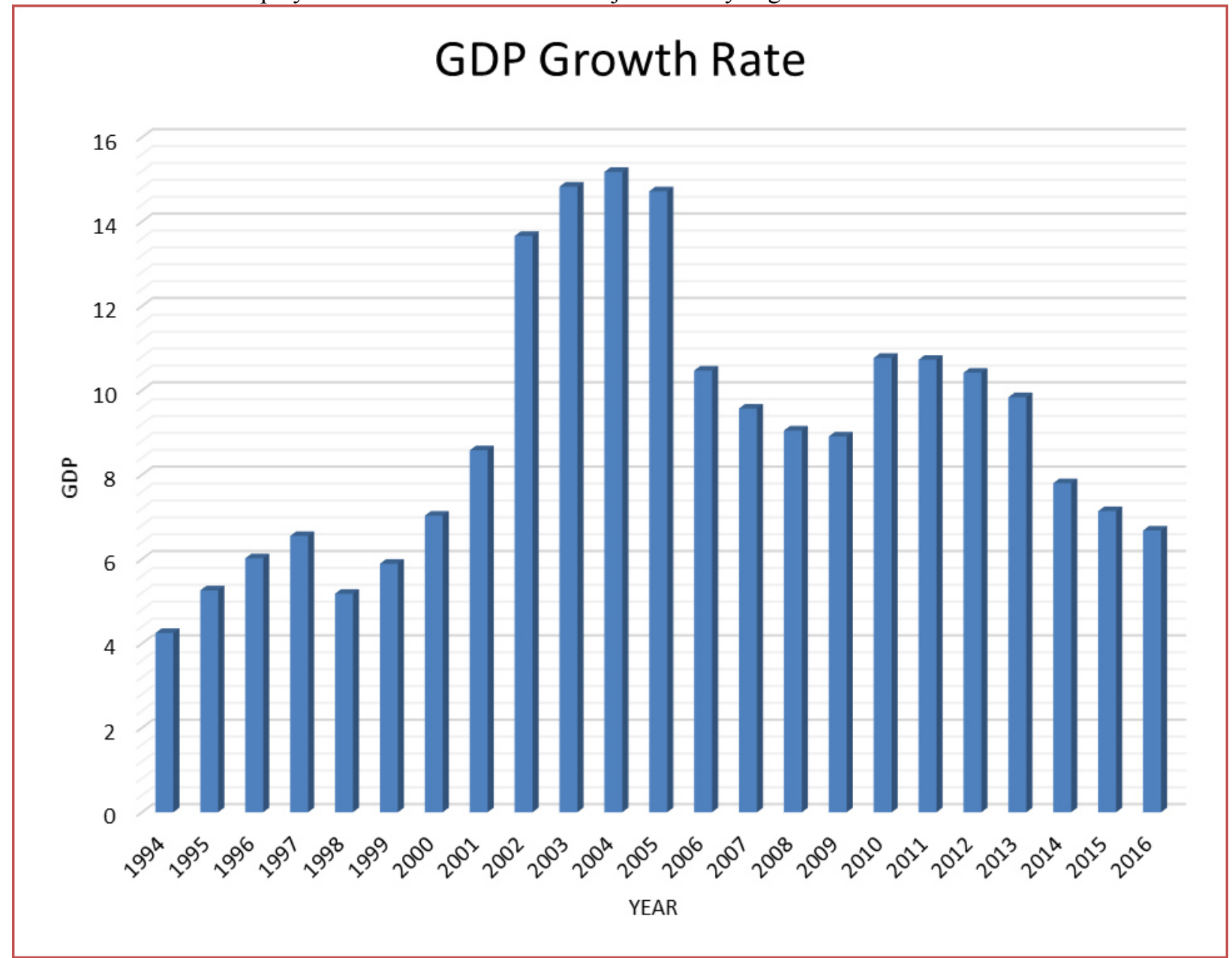

Figure 4.1: Analysis of data series from GDP Growth rate by the author.

Figure 4.1 above shows the histogram of the GDP growth rate in Nigeria. It shows the level of GDP Growth rate for each year, and we can observe that in 2004 GDP was at its highest GDP growth rate while it was at its lowest in 1994. It can be deduced that in earlier years, GDP was quite low compared to the later years though there have been fluctuations in the growth rate. GDP growth rate has since 2012 taken a downturn up till 2016; we can then infer that the GDP growth rate was highest between 2002 and 2005. 


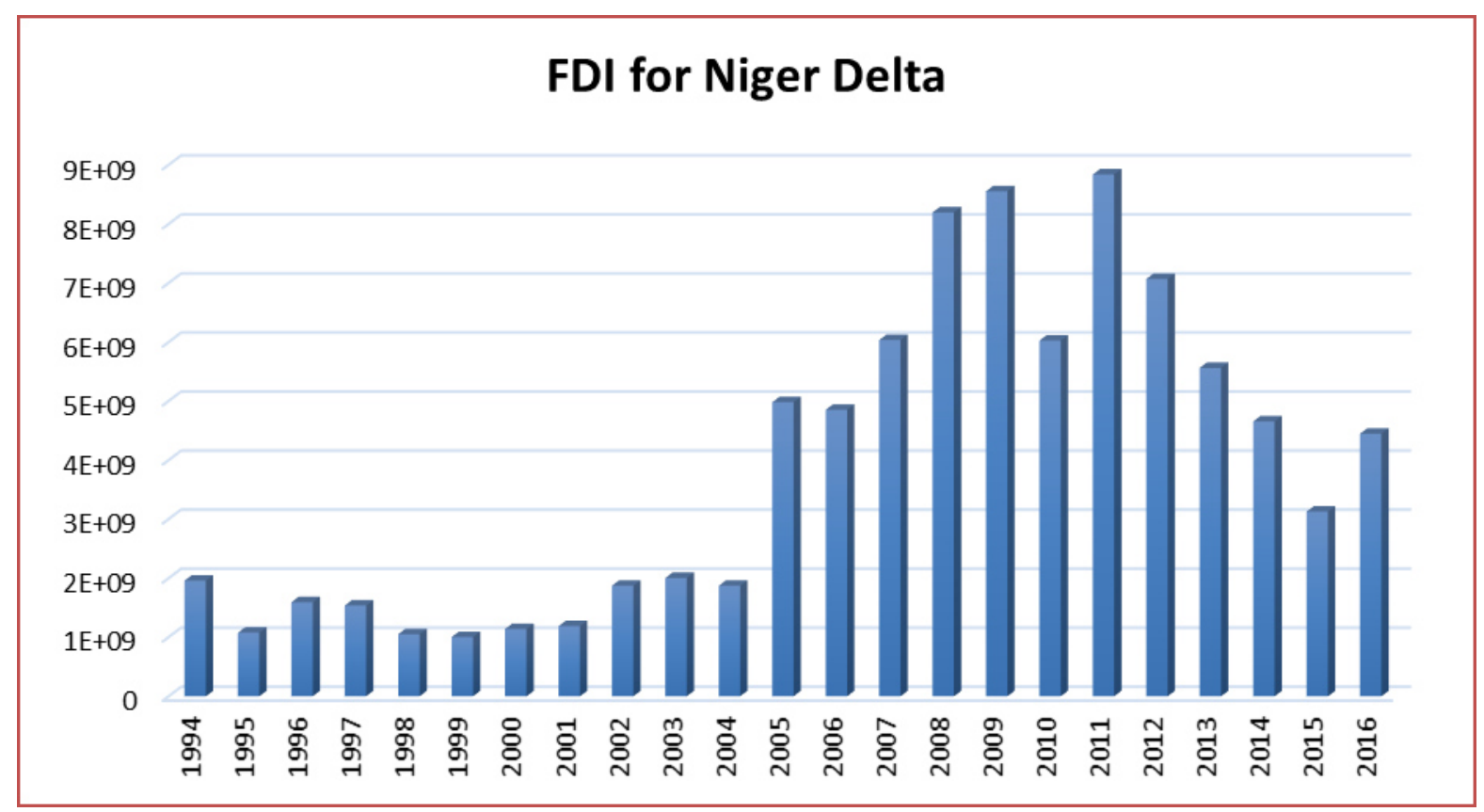

Figure 4.2: Histogram of FDI in Niger Delta by the author.

Figure 4.2 shows the histogram for Resource Seeking FDI in the Niger Delta from 1994 to 2016. The data represent Resource Seeking FDI in the Niger Delta, which is yearly data. From the histogram of FDI in the Niger Delta displays variations in FDI over the years, it can be observed that from 2005 FDIs have been on the increase until 2016 though with variations also. FDIs were at their peak in 2011, and they kept decreasing after that until an increase was noticed in 2016.

So far, the summaries in terms of figures of all the variables considered in this study have been given. Each variable was expressed in a plot and histogram. This shows the fluctuations of occurrence of the variables, i.e., the movement and pattern of the variables from 1994 to 2016.

\subsection{Unit Root Test}

Usually, most economic variables are non-stationary. It is therefore important to test for stationarity before generalising any relationships. Having described the characteristics of the data, testing the order of integration using the ADF, P.P. and KPSS unit root tests were undertaken. The results of the unit root test are reported in the tables below.

Table 4.3: Unit Root Test with ADF

\begin{tabular}{|l|l|l|l|l|l|}
\hline Variable & Level & First diff. & $5 \%$ Crit. Value & $1 \%$ Crit. Value & Int. Order \\
\hline RGDP & -1.9206 & -2.0006 & 0.6026 & 0.5722 & $\mathrm{I}(1)$ \\
\hline FDI & -1.0583 & -0.9522 & 0.912 & 0.9276 & $\mathrm{I}(1)$ \\
\hline
\end{tabular}

Table 4.4: Unit Root Test with P.P.

\begin{tabular}{|l|l|l|l|l|l|}
\hline Variable & Level & First diff. & $5 \%$ Crit. Value & $1 \%$ Crit. Value & Int. Order \\
\hline RGDP & -4.5392 & -4.5957 & 0.8411 & 0.8373 & $\mathrm{I}(1)$ \\
\hline FDI & -5.9526 & -0.5072 & 0.7464 & 0.8054 & $\mathrm{I}(1)$ \\
\hline
\end{tabular}

Table 4.5: Unit Root Test with KPSS

\begin{tabular}{|l|l|l|l|l|l|}
\hline \hline Variable & Level & First diff. & $5 \%$ Crit. Value & $1 \%$ Crit. Value & Int. Order \\
\hline RGDP & 0.32031 & 0.2528 & 0.3421 & 0.3322 & $\mathrm{I}(1)$ \\
\hline FDI & 0.79806 & 0.76896 & 0.6423 & 0.6155 & $\mathrm{I}(1)$ \\
\hline
\end{tabular}

The results of the three unit-root tests are reported above. At the $1 \%$ significance level, the results of the $\mathrm{ADF}$ unit root test suggest that all variables are integrated of order one, $I$ (1) process. The absolute value of the ADF test is greater than the absolute critical value at $1 \%$. Hence, they are stationary. However, the P.P. and KPSS unit root tests show that all variables are stationary at the first difference at $1 \%$ and $5 \%$ significance levels. The ADF test often has weak power when the sample size of a study is small, so the use of the results provided by P.P. and KPSS unit root tests is preferred; for this reason, we surmised that the variables could be well characterised as $I$ (1) process.

Note: The values in brackets are the significant values at $5 \%$ and $1 \%$. The optimal lag order for the ADF test is 
determined by AIC, while the bandwidths for P.P. and KPSS tests are determined by using the Dickey-Fuller Z (alpha) and KPSS Level, respectively. Since the problem of the ADF test is a sample size and using other stationarity tests helped without changing the sample size.

\subsection{Parameter estimation of the variables}

The objective of this study is to investigate the impact of some independent variables in the Niger Delta on the Gross Domestic Product (GDP) in Nigeria. This factor is FDI in the Niger Delta. A regression analysis was carried out to determine the impact of the variable on the Gross Domestic Product (GDP). The fitted regression linear model for the data is shown below:

Table 4.6: Ordinary Least Square Estimation

\begin{tabular}{|l|l|l|l|l|}
\hline Variable & Coefficient & Std. Error & t-Statistic & Prob. \\
\hline C & -10771289 & 8933137. & -1.205768 & 0.2435 \\
\hline FDI & -0.000776 & 0.000334 & -2.323132 & 0.0521 \\
\hline R-squared & 0.997259 & Mean dependent var & 34820886 \\
\hline Adjusted R-squared & 0.996650 & S.D. dependent var & 33318904 \\
\hline S.E. of regression & 1928504. & Akaike info criterion & 31.97205 \\
\hline Sum squared resid & $6.69 \mathrm{E}+13$ & Schwarz criterion & 32.21889 \\
\hline Log-likelihood & -362.6785 & Hannan-Quinn criteria. & 32.03413 \\
\hline F-statistic & 1637.236 & Durbin-Watson stat & 0.790551 \\
\cline { 1 - 2 } Prob(F-statistic) & \multicolumn{2}{|l}{} & \\
\cline { 1 - 3 } & &
\end{tabular}

The fitted model from the table shown above is given as:

GDP growth rate $=38.937175845+3.52490274078 \mathrm{e}-10 * \mathrm{FDI}$

Table 4.6 above is a result output using Ordinary Least Squares (OLS) to estimate the parameters. It shows that FDI is significant at a $5 \%$ level.

The table shows the constant estimate to be -10771289 . The table also shows a negative estimate for RS-FDI as -0.00776 contribution to GDP per capita in Nigeria.

Other results produced from the table are a standard error, $\mathrm{t}$ - statistic and probability values of the independent variables. It shows $8933137,-1.205768$, and 0.2435 as standard error, t- statistic and probability values, respectively, for the constant value. Also, it also shows $0.000334,-2.323132$ and 0.0521 respectively as standard error, t- statistic and probability values for FDI.

The model above shows that the coefficient of determination $\left(\mathrm{R}^{2}\right)$ is 0.997259 , with a standard error of 1928504; meaning that $99 \%$ of the total variation in GDP could be explained by the variations in FDI, while $0.002741 \%$ could be explained by other variables not used in the model.

\subsection{Estimation of Growth-Augmented Model}

The previous sections showed the properties within the various time-series data. The next section will show multivariate regression that is processed for variables used in the research.

Table 4.7: Estimates of Economic Growth and Foreign Direct

Investment in Nigeria (1994-2016)

\begin{tabular}{|c|c|c|}
\hline \multirow[t]{2}{*}{$\begin{array}{l}\text { INDEPENDENT } \\
\text { VARIABLES }\end{array}$} & $\begin{array}{l}\text { MODEL I: COEFFICIENTS (WITHOUT } \\
\text { CORRECTION }\end{array}$ & $\begin{array}{l}\text { MODEL II: COEFFICIENTS (WITH } \\
\text { CORRECTION }\end{array}$ \\
\hline & FOR (AUTOCORRELATION) & FOR AUTOCORRELATION) \\
\hline \multirow[t]{2}{*}{ CONSTANT } & $3.89 \mathrm{E}+02$ & $31.11+\mathrm{E} 01$ \\
\hline & $(0.00385)^{* *}$ & $(0.00562)^{* *}$ \\
\hline \multirow[t]{2}{*}{ RSFDI } & $3.53 \mathrm{E}-10$ & $4.88 \mathrm{E}-10$ \\
\hline & $(0.43254)$ & $(0.19122)$ \\
\hline \multirow[t]{2}{*}{$\operatorname{AR}(1)$} & \multirow[t]{2}{*}{-} & $8.03 \mathrm{E}-01$ \\
\hline & & $(0.00494)^{* *}$ \\
\hline R-SQUARED & 0.4924 & 0.6853 \\
\hline $\begin{array}{ll}\text { ADJUSTED } & \text { R- } \\
\text { SQUARED } & \end{array}$ & 0.3796 & 0.5928 \\
\hline F-STATISTIC & 4.365 & 7.404 \\
\hline PROB(F-STATISTIC) & 0.01215 & 0.0007522 \\
\hline
\end{tabular}

Note: $* * *(* *) *$ represent $1 \%, 5 \%$ and $10 \%$ level of significance. P-values are in parentheses.

Table 4.7 above shows the estimates and contribution of the factors contributing to GDP in Nigeria. The table's result is subdivided into two. The model 1 part shows the significance of the economic variables before the auto-correlated error problem was corrected, while model II shows when the errors have been corrected. Considering the result from a model I and II, it could be seen that resource seeking FDI in Niger Delta do not 
contribute to the Gross Domestic Product (GDP) of Nigeria as the p-value produced by RSFDI gives 0.43254 and 0.19122 for model I and model II respectively. It could also be seen that model II also has overall model significance as the p-value (0.0007522) is less than 0.05 , which shows the correctness of the model used.

\subsection{Hypothesis Testing}

$H_{\text {.O.: }}$ RSFDI in the Niger Delta does not contribute positively to Nigeria's GDP growth.

$\mathrm{H}_{\text {.A.: }}$ RSFDI in the Niger Delta contributes positively to Nigeria's GDP growth.

Table 4.8: Correlations - Hypothesis

\begin{tabular}{|c|c|c|c|c|c|c|c|}
\hline \multirow[t]{2}{*}{ Model } & \multicolumn{2}{|c|}{$\begin{array}{l}\text { Unstandardised } \\
\text { Coefficients }\end{array}$} & $\begin{array}{l}\text { Standardised } \\
\text { Coefficients }\end{array}$ & \multirow[t]{2}{*}{$\mathrm{T}$} & \multirow[t]{2}{*}{ Sig. } & \multicolumn{2}{|c|}{$\begin{array}{l}\text { Collinearity } \\
\text { Statistics }\end{array}$} \\
\hline & $\mathrm{B}$ & Std. Error & Beta & & & Tolerance & VIF \\
\hline (Constant) & 3.107 & 1.459 & & 2.130 & .045 & & \\
\hline RSFDI & $5.271 \mathrm{E}-010$ & .000 & .344 & 1.681 & .108 & 1.000 & 1.000 \\
\hline
\end{tabular}

The result of the table above shows that RSFDI in the Niger Delta contributes negatively to Nigeria's GDP growth as it returns a negative coefficient of 5.271E-010. It shows that the contribution of FDI to economic growth in Nigeria is negative. The p-value of 0.108 shows a significant value that is greater than $1 \%$. It means failure to reject the null hypothesis due $\left(\mathrm{H}_{\mathrm{o}}\right.$ due to the confidence interval and conclude that RSFDI in Niger Delta does not contribute positively to Nigeria's GDP growth. This simply implies that RS-FDI in Niger Delta has no impact on the growth per capita of Nigeria and particularly on the welfare of the citizens of the nation.

However, from the data, RSFDI contribution to GDP growth is negligible. The possible reason for this outcome is that most profit from RSFDI is often repatriated to the home countries or offshore headquarters of the investors. Therefore, there is a little trickledown effect on the economy of Nigeria.

\section{CONCLUSION}

It was found from the analyses that the RSFDI effect on GDP growth is negligible. This result for policymakers implies that they should refocus to identify the nature of FDI that will harness the natural resources in the Niger Delta for Nigeria's economic growth. Research finding on the relationship between RSFDI and GDP growth is that RSFDI contributes to GDP growth in the Niger Delta. However, the observed results indicate that although increases in RSFDIs contribute to GDP growth in the Niger Delta, the recorded growths are marginal and not capable of increasing the economic status of the region substantially. A possible reason that justifies the above research finding on the relationship between RSFDI and the GDP growth in the Niger Delta is the problem of profit repatriations. Most of the earnings by the oil and gas multinational companies are often sent back to the offshore headquarters; hence, little value is derived from the profit accruing from oil and gas explorations. Most of these oil and gas multinationals also do not locate their Nigerian head offices in the Niger Delta. Their Nigerian head offices are located in Lagos, south-west of Nigeria. As a result of this, the Niger Delta does not enjoy the developmental benefit of having the head offices of these oil and gas companies in their region. Since their head offices are located in Lagos, major transactions of the companies and the spending of their senior management and staff, which contributes to the flow of income and hence GDP growth, happens in Lagos and not in the Niger Delta.

\section{References}

ADB; 2017a. African Economic Outlook, Abidjan: African Development Bank Group.

Agosin, M.R. and Machado, R. (2005) Foreign investment in developing countries: does it crowd in domestic investment? Oxford Development Studies. Vol. 33, pp. 149-162.

Ajide, K.B. and Osode, O.E., 2017. Does FDI dampen or magnify output growth volatility in the ECOWAS region? African Development Review, 29(2), pp.211-222

Akhtaruzzaman, M., Berg, N. and Lien, D., 2017. Confucius Institutes and FDI flows from China to Africa. China Economic Review, 44, pp.241-252.

Akpan, U. S., Isihak, S.R. and S. A. Asongu, S.A., 2014. "Determinants of Foreign Direct Investment in FastGrowing Economies: A Study of BRICS and MINT," African Governance and Development Institute W.P./14/002.

Ali, M. and Malik, I.R., 2017. Impact of Foreign Direct Investment on Economic Growth of Pakistan.

Allen, T., 2017. Gross domestic product: an economy is all in finance and development. [online]. International Monetary Fund. Available from: http://www.imf.org/external/pubs/ft/fandd/basics/gdp.htm [Accessed August 21 2019].

Allwell, O., 2018. Agricultural development and employment generation in Nigeria. International Journal of Advanced Studies in Ecology, Development and Sustainability, 5(1), pp. 1-22. 
Anyanwu, J.C., 2006. Promoting investment in Africa. African Development Review, 18(1), pp.42-71.

Asiedu, E. 2013. Foreign direct investment, natural resources and institution: A working paper. Department of Economics, University of Kansas, [Online], Available: https://www.theigc.org/wpcontent/uploads/2014/09/Asiedu-2013-Working-Paper.pdf [February 9 2017]. Available from: linkinghub.elsevier.com/retrieve/pii/S157406840501107x [Accessed June 13 2019].

Ayanwale, A.B., 2007. FDI and economic growth: Evidence from Nigeria. [online]. African Research Consortium: Nairobi. Available from: https://www.africaportal.org/publications/fdi-and-economic-growthevidence-from-nigeria/. [Accessed June 5, 2018].

Banerji, S., 2013. Effects of foreign direct investment in the Indian economy. [Online]. Available from: https://halshs.archivesouvertes.fr/file/index/docid/846825/filename/Effects_of_Foreign_Direct_Investment_in_the_Indian_Econo my.pdf [Accessed June 5, 2018].

Bjorvatn, K., 2008. The theory of environmental degradation and Economic growth. Journal of the environment.

Borensztein, E., Gregorio, J.D. and Lee, J.W., 1998. How does foreign direct investment affect economic growth? Journal of International Economics, Vol. 45, pp. 115-135.

Brezina, C., 2011. Understanding the gross domestic product and the gross national product. The Rosen Publishing Group, Inc.Brincikova, Z. and Darmo, L., 2014. The impact of FDI inflow on employment in V4 countries. European Scientific Journal.

Buckley, Obe, P.J. and Boddewyn, J.J., 2015. The internalisation of societal failures by multinational enterprises. The Multinational Business Review, 23(3), pp.170-187.

Chakrabarti, A., (2001), "The Determinants of Foreign Direct Investments: Sensitivity Analyses of CrossCountry Regressions," Kyklos, 54(1), 89-114.

Carkovic, M., and Levine, R., 2002. Does foreign direct investment accelerate economic growth? In H. T. Moran, E.Graham, \& M. Blomstrom (Eds.),Does FDI promote development? Washington, DC: Institute for International Economics

Costinot, A. and Donaldson, D., 2012. Ricardo's theory of comparative advantage: old idea, new evidence. American Economic Review, 102(3), pp.453-58.

Cukrowski, J. and Fischer, M.M., 2000. Theory of comparative advantage: Do transportation costs matter?. Journal of Regional Science, 40(2), pp.311-322.

Dickson, M.E. and Ezirim, G.E., 2017. The political economy of the recession in Nigeria's fourth republic. African Journal of Political Science and International Relations, Vol. 11, No. 7, pp. 193-200.

Dima, S. C., 2010. From international trade to firm internationalisation. European Journal of Interdisciplinary Studies. Vol. 2, No. 2. pp. 8-15.

Dunning, J.H., 2000. The eclectic paradigm as an envelope for economic and business theories of MNE activity. International business review, 9(2), pp.163-190

Ejuvbekpokpo, S., 2012. Cost of Governance on Economic Development in Nigeria. Global Journal of Business Management and Research, 12(13), pp. 56-62.

Faeth, S., 2009. Determinants of foreign direct investment - a tale of nine

Fadhil, M.A. and Almsafir, M.K., 2015. Role of FDI inflows in economic growth in Malaysia (Time Series: 1975-2010). Procedia Economics and Finance, 23, pp. 1558-1566.

Fosu, A.K., 2017. Growth, inequality, and poverty reduction in developing countries: recent global evidence. Research in Economics, 71(2), pp.306-336.

Gokmenoglua, K.K., Apinran, M.O., Nigar, T., 2018. Impact of Foreign Direct Investment on Human Development Index in Nigeria, Business and Economics Research Journal, Volume 9 Number 1.

Gonchar, K. and Marek, P., 2013. Natural-resource or market-seeking FDI in Russia? An empirical study of locational factors affecting the regional distribution of FDI entries (No. 3/2013). IWH Discussion Papers.

Gorg, H. and Greenaway, D., 2003. Much ado about nothing? Do domestic firms benefit from foreign direct investment? [Online]. Available from: https://www.econontor.eu/bitstream/10419/30391/1/dp944.pdf [Accessed July 5, 2019].

Hale, G. and Xu, M., 2016, September. FDI effects on the labour market of host countries. Federal Reserve Bank of San Francisco.

Haller, A., Concepts of economic growth and development, challenges of crisis and knowledge. Economy Transdisciplinary CoGNPtion, Vol. 12, No. 1, pp. 66-71.

Harris, D.J., 2007. The classical theory of economic growth. Stanford University, USA.

Hattari, R. and Rajan, R.S., 2008. Sources of FDI flows to developing Asia: The roles of distance and time zones.

Inekwe, J.N., 2013. FDI, employment and economic growth in Nigeria. African Development Review, 25(4), pp.421-433.

Iyoha, F. O., Gberevbie, D. E., Iruonagbe, C. T. \& Egharevba, M. E., 2015. Cost of Governance in Nigeria: In Whose Interest?. International Journal of Social, Behavioral, Educational, Economic, Business and 
Industrial Engineering, 9(1).

Janicki, H. P. and P. V. Wunnava, P.V., 2004. "Determinants of Foreign Direct Investment: Empirical Evidence from E.U. Accession Candidates," Applied Economics, 36(5), 505-509.

Johansen, S. 1991. "Estimation and hypothesis testing of cointegration vectors in Gaussian vector autoregressive models". Econometrica. 59: 1551-1580.

Johansen, S. 1995. Likelihood-based inference in cointegrated vector autoregressive models. Oxford: Oxford University Press.

Jude, C., 2019. Does FDI crowd out domestic investment in transition countries?. Economics of Transition and Institutional Change, 27(1), pp.163-200.

Keuschnigg, M. 1999. Comparative advantage in international trade: theory and evidence. Studies in Empirical Economics. Springer-Verlag Company.

Khachoo, A.Q. and Khan, M.I., 2012. Determinants of FDI inflows to developing countries: a panel data analysis.

Kinoshita, Y. and Campos, N.F., 2003. Why does FDI go where it goes?

Kneller, R. and Pisu, M., 2007. Industrial linkages and export spillovers from FDI. World Economy, 30(1), pp.105-134.

Lanza, V., 2012. The Classical Approach to Capital Accumulation - Classical Theory of Economic Growth, Umea University.

Lamsiraroj, S. (2016) The foreign direct investment-economic growth nexus. International Review of Economics and Finance. Vol. 42, pp. 116-133.

Lane, P.R., 2015. Cross-border financial linkages: Identifying and measuring vulnerabilities. CEPR Policy Insight, (77).

MBNP, 2017. Economic Recovery and Growth Plan, Abuja: Ministry of Budgets and National Planning.

Morgan, R.E. and Katsikeas, C.S., 1997. Theories of international trade, foreign direct investment and firm internationalisation: a critique. Management decision, Vol. 35, No, 1, pp.68-78.

Muinelo - Gallo, L. and Roca - Sagalés, O., 2011. Economic growth and inequality: the role of fiscal policies. Australian Economic Papers, 50(2 - 3), pp.74-97.

Negichi, T., 2014. Developments of International Trade Theory, Advances in Japanese Business and Economics, Springer Science, pp.19-22.

NEITI, 2017. Unremitted Funds, Economic Recovery, and Oil Sector Reform. [online]. Abuja: Nigeria Extractive Industries Transparency Anitiative. Available from: http://www.neiti.gov.ng/phocadownload/NEITI-PB3-280317.pdf. [Accessed August 25, 2018]. Nigeria: Economic, biodiversity, and public health concern. The scientific World Journal, 8, pp. 811-818.

OECD, 2008. OECD Benchmark Definition of Foreign Direct Investment FOURTH EDITION 2008. [online]. Available from: https://www.oecd.org/daf/inv/investmentstatisticsandanalysis/40193734.pdf. [Accessed July 5, 2019].

Ogunkola, E.O. and Jerome, A., 2006. Foreign direct investment in Nigeria: Magnitude, direction and prospects. Foreign Direct Investment.

Oh, E., 2017. Nigeria's Services Economy: The Engine for Future Growth, s.1.: U.S. International Trade Commission (USITC).

Okeke, I. M. \& Eme, O. I., 2015. Cost of Governance and its Implications on Nigeria's Economy. Kuwait Chapter of Arabian Journal of Business and Management Review, 4(5).

Patterson, N.K., Montanjees, M., Cardillo, C. and Motala, J., 2004. Foreign direct investment: trends, data availability, concepts, and recording practices. International Monetary Fund.

Pegkas, P., 2015. The impact of FDI on economic growth in Eurozone countries. The Journal of Economic Asymmetries, 12(2), pp.124-132.

Pogge, T., 2008. Growth and inequality: recent understanding trends and political choices. Dissent, 55(1), pp.6675.

Ruiz - Vergara, J. (2017). Financial development, institutional investors, and economic growth. International Review of Economics and Finance, 54, 218-224.

Salvadori, N. and Signorino, R., 2017. From endogenous growth to stationary state: The world economy in the mathematical formulation of the Ricardian system. The European Journal of the History of Economic Thought, 24(3), pp.507-527.

Sapsford, D., 2008. Smith, Ricardo and the world marketplace, 1776-2007: Back to the future? The companion to Development Studies. Available from: https://books.google.com.ng/books?hl=en\&lr=\&id=UO3vCiWw$\mathrm{xwC} \&$ oi $=$ fnd\&pg $=$ PA75\&dq=labour, + internal + mobile + resource, + david + ricardo\&ots $=$ e8gRf2d7Lj\&sig=Q Sp0GMO7Wq_Q13ohZ_n01KkRf44\&redir_esc=y\#v=onepage\&q\&f=false [Accessed December 14, 2020].

Schumacher, R., 2012. Adam Smith's theory of absolute advantage and the use of doxography in the history of 
economics. Erasmus, Vol. 5, No. 2, pp. 54-80.

Seddighi, H.R., Lawler, K.A. and Katos, A.V., (2000). Econometrics: a practical approach. Routledge: London.

Sengupta, J., 2011. Understanding economic growth: Morden theory and experience. Springer, London.

Shah, M.H., 2014. The significance of infrastructure for FDI inflow in developing countries. Journal of Life Economics, 1(2), pp.1-16.

Shell, 2019. Economic Contribution. [online]. Available from: https://www.shell.com.ng/media/nigeria-reportsand-publications-briefing-notes/economic-contribution.html. [Accessed February 12, 2019]

Silber, J., 2013. Economic Studies in Inequality, Social Exclusion and Well-Being. Springer Open: London.

Smaouli, H. and Nechi, S., 2017. Does sukuk market development spur economic growth? Research in International Business and Research, Vol. 41, pp. 136-147.

UNCTAD, 2007. World investment report. [online]. Geneva, Switzerland. Available from: https://unctad.org/en/pages/PublicationArchive.aspx?publicationid=724. [Accessed March 12, 2018 ].

UNCTAD (2015). World Investment Report. [online]. Geneva, Switzerland. Available from: https://unctad.org/en/PublicationsLibrary/wir2015 en.pdf. [Accessed December 14, 2020].

UNCTAD, 2016. investor nationality: policy challenges. [online]. United Nations Conference on Trade and Development, Geneva. Available from: https://unctad.org/en/PublicationsLibrary/wir2016 en.pdf [Accessed June 13, 2019].

Uttama, N.P., 2012. A Survey on Socio-economic Development and FDI-led Strategy. Procedia Economics and Finance, Vol. 1, P.P. $393-400$.

Van den Bergh, J.C., 2009. The GDP paradox. Journal of Economic Psychology, 30(2), pp.117-135.

Vijayakumar, N., Sridharan, P. and Rao, K. C. S., 2010. "Determinants of FDI in BRICS Countries: A Panel Analysis," International Journal of Business Science and Applied Management, 5(3), 1-13.

Wacker, K.M., 2016. (When) Should We Use Foreign Direct Investment Data to Measure the Activities of Multinational Corporations? Theory and Evidence. Review of International Economics, 24(5), 980-999.

World Bank, 2014. Foreign direct investment flows into Sub-Saharan Africa. [online]. World Bank Group, Washington DC. Available from: http://documents.worldbank.org/curated/en/505071468203651135/Foreign-direct-investment-flows-intoSub-Saharan-Africa [Accessed December 11, 2020).

World Bank, 2019. The World Bank Data: Nigeria. [online]. Available from: https://data.worldbank.org/country/nigeria?view=chart. [Accessed December 12, 2019].

Zhang, W.B., 2008. Capital, knowledge, structure of money, and prices over time. [online]. Available from: http://www.springer.com/cda/content/document/cda downloaddocument/9783540782643c1.pdf?SGWID=0-0-45-838700-p173807739. [Accessed December 11 2017]. 